\title{
Special Education Program at Princess Nourah University: Evaluation of Program Alignment with the Standards of the Council for Exceptional Children (CEC)
}

\author{
Ola Abusukkar, Ph.D. \\ Princess Nourah bint Abdulrahman University \\ Email: Dr.ola.sukkar@gmail.com \\ Areej Ahmed Ph.D.* \\ Gladys W. \& David H. Patton College of Education, Ohio University \\ E-mail: Ahmeda@Ohio.edu \\ Dianne Gut Ph.D. \\ Gladys W. \& David H. Patton College of Education, Ohio University \\ E-mail: Gut@Ohio.edu
}

The research is financed by Princess Nourah bint Abdulrahman University in Saudi Arabia.

\begin{abstract}
This study evaluated the extent to which the special education program in the College of Education at Princess Nourah University (PNU) in the Kingdom of Saudi Arabia aligns with the standards of the Council for Exceptional Children (CEC). The research utilized a mixed-method approach to examine the preparedness of pre-service special educators currently enrolled in their last year of the special education program. Surveys were used to explore the perceptions of five hundred pre-service teachers of their teacher preparation program as related to the seven standards from CEC's initial special educator preparation standards.
\end{abstract}

Keywords: pre-service special education teachers, and Council for Exceptional Children, CEC's initial special educator preparation standards.

DOI: $10.7176 /$ RHSS/10-14-01

Publication date:July $31^{\text {st }} 2020$

\section{Introduction}

The roles and responsibilities of in-service teachers in special education can be overwhelming. They are responsible to work with many individuals with a range of abilities, plan and differentiate instructions in addition to managing students' documentation and paperwork. Therefore, teacher preparation programs must be wellequipped with strong standards to prepare pre-service teachers (those training to be teachers) in special education. Needless to say, strong preparation programs for pre-service teachers can eliminate many difficulties that future teachers in special education may face. Aldabas (2015) stated that in Saudi Arabia, special education is not part of the curriculum required for the teacher education programs for general education pre-service teachers. Aldabas further added that to have a strong special education program in the schools, teachers must have strong knowledge and skills to provide high quality education to students with special needs.

The aim of this study was to evaluate pre-service special education program in preparing pre-service teachers to work with individuals with disabilities. The researchers identified the following questions to evaluate the program at PNU:

1. What are the pre-service special education teachers' perceptions of the teacher preparation program in the college of education at Princess Norah University in Saudi Arabia?

2. What are the strengths, opportunities for growth and recommended changes for the current pre-service special education program at PNU?

\section{Literature Review}

Numerous studies discussed the characteristics and elements of successful pre-service special education programs. Brownell et al. (2005) identified seven common practices found in effective education preparation programs. These practices include 1) designing comprehensive coursework for pre-service teachers, 2) teaching special education policies and theories to help pre-service teachers establish a strong background in special education, 3) requiring intensive filed experience to enhance pre-service skills, 4) linking theories to practicum to reduce the gap that preservice teachers face during their filed experience, 5) providing extensive training to faculty members to work with pre-service teachers from different backgrounds,6) training pre-service teachers to better communicate with their mentors and future students, 7) emphasizing the importance of collaboration among faculty members, preservice, and in- service teachers. Mason-William, Frederick, and Mulcahy (2014) stated that one of the most 
importance factors in designing special education programs is to maximize the ability of pre-service special educators for doing research. They must have a wide-range of knowledge regarding interventions and be able to design a usable intervention based on evidence-based practices. These knowledge and skills must be integrated throughout a well-designed preparation program. The program should provide opportunities for pre-service special educators to become familiar with research findings, link the results with evidence-based practices, and implement these practices into their own teaching practices. All recommendations from Mason-William et al. (2014) are aligned with the CEC standards, ensuring special education programs provide extensive and rich practical field experiences based in best-practice. Brownell et al. (2005) reviewed special education programs in fifty-two institutions in the US to determine critical features of effective programs, to identify the critical factors of special education teacher preparation at both the undergraduate and graduate levels. The researchers found there is limited research in the field of pre-service preparation in the US when compared with other fields. They suggested improving the quality of preparation programs for beginning special education teachers by including comprehensive and intensive field experiences linked with the acquisition of content knowledge.

\section{Special education teacher preparation in Saudi Arabia:}

Teacher preparation programs are tasked with preparing special educators for a range of education settings, and strong special education program can have a considerable impact on the quality of pre-service special educators. Currently, in Saudi Arabia, the field of special education is developing. A well-planned special education program significantly increased the quality of pre-service special educators (Al-Hiary, Almakanin and Tabbal, 2015). Needless to say, strong preparation programs for pre-service teachers can eliminate many difficulties that future teachers in special education may face.

Aldabas (2015) stated that in Saudi Arabia, special education is not part of the curriculum required for the teacher education programs for general education pre-service teachers. Aldabas further added that to have a strong special education program in the schools, teachers must have strong knowledge and skills to provide high quality education to students with special needs. Murry and Alqahtani (2015) conducted a study that examined the knowledge of 52 pre-service teachers who graduated from major Saudi Arabian universities regarding special education laws and ethics, and how this knowledge maximized their skills in providing high quality services for individuals with disabilities. Results indicated that pre-service teachers did not have adequate knowledge of the laws and practices in special education, however, they strongly believed in the rights of individuals with disabilities, and wished to receive more training in special education. It is imperative to design high quality teacher preparation programs in special education to fill the existing gap in education and prepare competent future educators.

\section{Method}

This study utilized a mixed-method sequential design. It is conducted in two phases with the emphasis being on the first quantitative phase, followed by a second qualitative phase. Integration of the quantitative and qualitative findings occurs during a third integration phase. According to Creswell, (2008) mixed methods using quantitative and qualitative data provide in-depth information regarding the problem or topic being studied.

\section{Participants}

The sample consisted of 500 pre-service special education teachers in the special education program at PNU in the last semester of the program and enrolled in a practicum course which included a panel discussion focused on autism and behavioral disorders. A follow-up group interview was held with four pre-service teachers and four inservice teachers who graduated from, or were currently enrolled in the special education program at PNU. The inservice teachers graduated within six months of the start of the study.

\section{Data collection and procedures}

The first phase used a questionnaire to collect data from pre-service special education teachers which was administered via Qualtrics, an online software tool. A link to the questionnaire was sent to participants following approval from the Institutional Review Board governing research with Human Subjects. The delivery of the survey followed Dillman's recommendations for survey research. A link to the survey was distributed and kept open for six weeks. Weekly email reminders were sent to all non-responders.

In the second phase of the study, group interviews were used to investigate the strengths and opportunities for growth in the autism and behavioral disorder track in the special education program at PNU. Questions also addressed the program's alignment with the seven standards for beginning special education teachers from the Council for Exceptional Children (CEC). The first author organized and conducted two group interviews using an interview guide developed from the quantitative findings in this study. Four participants were randomly selected from in-service special education teachers who graduated from the special education program in the College of Education at PNU within the last year, and four pre-service teachers currently enrolled in their last semester in the 
special education program at PNU. Prior to the start of the group interview, participants were asked to complete a demographic sheet to collect data such as age, job title, experience, work place education and training.

\section{Data Analysis}

Quantitative data was analyzed using SPSS. Ordinal data was analyzed using frequencies and interval data was analyzed for means and standard deviations. Confidence intervals were also estimated for means to responses using the formula presented in Table 1 . The range is calculated, where it equals $5-1=4$. The length of the interval was then calculated by dividing the range by the number of categories (options), then $4 / 5=0.80 \cdot$ the first category of arithmetical values is: 1 to $1+0.80$. Thus, for the rest of the values of the arithmetic mean, the following table shows the method of interpreting the values of the arithmetic mean:

Table 1 Confidence Interval Estimates for Response Means

\begin{tabular}{|l|l|l|}
\hline Minimum mean & Maximum mean & Response \\
\hline 1 & Less than 1.8 & Very low \\
\hline 1.8 & Less than 2.6 & Low \\
\hline 2.6 & Less than 3.4 & Medium \\
\hline 3.4 & Less than 4.2 & High \\
\hline 4.2 & 5 & Very high \\
\hline
\end{tabular}

The sample response was analyzed through calculating the frequency rate for each response to the total sample.

Using both qualitative and quantitative methods allowed for more in-depth information about perceptions, insights, attitudes, experiences, and beliefs of pre-service and in-service special education teachers regarding their program of study in special education program at PNU in the Kingdom of Saudi Arabia.

\section{Results}

To answer the first question "What are the pre-service special education teachers' perceptions of the teacher preparation program in the college of education at Princess Norah University in Saudi Arabia?, the arithmetic mean and standard deviation of the pre-service Special Education teachers' responses to each item of the first domain were calculated.

Table 2 shows the rankings that were arranged due to the mean of the sample response on each standard and its standard deviation. Specifically, the data represents the effectiveness of Special Education Program of PNU in preparing female teachers to work with students with behavioral disorders and autism spectrum disorders. The mean of pre-service special education teachers' perceptions of their degree to which the program prepared them for each of the seven standards were all high and ranged from 3.48 to 3.94. Pre-service teachers' responses indicated that Standard 1 "Learner Development and Individual Learning Differences" was ranked first, with an arithmetic mean of (3.94), representing a high degree of satisfaction with their preparation. Ranked second was Standard 6 "Professional Learning and Ethical Practice" with an arithmetic mean of (3.91) (high). Next, Standard 7 "Collaboration" was ranked third with an arithmetic mean of (3.65). Standard 2 "Learning Environments" was ranked last with an arithmetic mean of (3.48) (high).

Table 2 Participants' Rankings of the Effectiveness of Special Education Program by CEC Standard

\begin{tabular}{llllll}
\hline Standard & $\begin{array}{l}\text { No. } \\
\text { items }\end{array}$ & $\begin{array}{l}\text { of } \\
\text { Mean }\end{array}$ & $\begin{array}{l}\text { Standard } \\
\text { deviation }\end{array}$ & Ranking & Responses \\
\hline $\begin{array}{l}\text { Learner Development and Individual } \\
\text { Learning Differences }\end{array}$ & 6 & 3.94 & 0.89 & 1 & High \\
$\begin{array}{l}\text { Learning Environments } \\
\text { Curricular Knowledge Content }\end{array}$ & 6 & 3.48 & 0.96 & 7 & High \\
Assessment & 6 & 3.61 & 0.96 & 4 & High \\
$\begin{array}{l}\text { Instructional Planning and Strategies } \\
\text { Professional Learning and Ethical }\end{array}$ & 5 & 3.51 & 0.99 & 6 & High \\
Practice & 5 & 3.57 & 1.00 & 5 & High \\
Collaboration & 5 & 3.91 & 0.95 & 2 & High \\
\hline
\end{tabular}

Focus Area One: Learner and Learning

Ratings of effectiveness related to standard one by element. To identify the highest-ranking elements in the special education teacher preparation program at PNU, the arithmetic mean and standard deviation of pre-service special education teachers' responses to each item comprising the seven standards of CEC were calculated.

Table 3 represents participants' ratings of satisfaction with their preparation relate to the elements associated with Standard 1: Learner Development and Individual Learning Differences. 
Table 3 Pre-service Special Education Teachers' Responses to the Elements Included in Standard 1: Learner Development and Individual Learning Differences

\begin{tabular}{|c|c|c|c|c|c|}
\hline No. & Element & $\begin{array}{l}\text { Arithmetic } \\
\text { Mean }\end{array}$ & $\begin{array}{l}\text { Standard } \\
\text { deviation }\end{array}$ & Ranking & Responses \\
\hline 1 & $\begin{array}{l}\text { Clarifying similarities and differences between the } \\
\text { students with special needs and the normal }\end{array}$ & 4.12 & 0.86 & 1 & $\begin{array}{l}\text { Extremely } \\
\text { high }\end{array}$ \\
\hline 2 & $\begin{array}{l}\text { Introduce the characteristics of students with } \\
\text { behavioral disorders and autism spectrum disorder } \\
\text { and ways to deal with them as distinct students. }\end{array}$ & 3.90 & 0.89 & 4 & High \\
\hline 3 & $\begin{array}{l}\text { Explaining the impact of special needs on the } \\
\text { educational pattern of students with behavioral } \\
\text { disorders and autism spectrum disorder. }\end{array}$ & 3.82 & 0.88 & 5 & High \\
\hline 4 & $\begin{array}{l}\text { Identifying the needs of students with behavioral } \\
\text { disorders and autism spectrum disorder. }\end{array}$ & 4.00 & 0.87 & 3 & High \\
\hline 5 & $\begin{array}{l}\text { Introducing the role that a family can play in } \\
\text { developing the educational aspects of students with } \\
\text { behavioral disorders and autism spectrum disorder. }\end{array}$ & 4.02 & 0.91 & 2 & High \\
\hline 6 & $\begin{array}{l}\text { Defining the different learning methods and } \\
\text { strategies for students with behavioral disorders and } \\
\text { autism spectrum disorder. }\end{array}$ & 3.80 & 0.94 & 6 & High \\
\hline Total & & 3.94 & 0.89 & - & High \\
\hline
\end{tabular}

Data in Table 3 reports a high level of perceived effectiveness (mean rating of 3.94) of the Special Education Program in the College of Education at PNU in preparing the female special education teachers to work with the students with behavioral disorders and autism spectrum disorders on Standard 1. The program was rated as most effective in preparing teachers to "clarify similarities and differences between the students with special needs and the normal" with a mean rating of 4.12 indicating a very high degree of satisfaction.

Ratings of effectiveness related to standard two by element. Table 4 represents pre-service teachers' ratings of satisfaction with their preparation related to the elements associated with Standard 2: Learning Environments.

Table 4 Pre-service Special Education Teachers' Responses to the Elements of Standard 2: Learning Environments

\begin{tabular}{|c|c|c|c|c|c|}
\hline No. & Element & $\begin{array}{l}\text { Arithmetic } \\
\text { Mean }\end{array}$ & $\begin{array}{l}\text { Standard } \\
\text { deviation }\end{array}$ & Ranking & Responses \\
\hline 7 & $\begin{array}{l}\text { Knowledge of the educational requirements in } \\
\text { planning the lessons for students with autism. }\end{array}$ & 3.41 & 0.94 & 5 & High \\
\hline 8 & Consolidating the use of educational technology. & 3.51 & 0.99 & 3 & High \\
\hline 9 & $\begin{array}{l}\text { Motivating the activation of group collaboration } \\
\text { and positive interaction of the students with } \\
\text { behavioral disorders and autism. }\end{array}$ & 3.55 & 0.99 & 2 & High \\
\hline 10 & $\begin{array}{l}\text { Acquiring the basics of dealing with a group of the } \\
\text { different cultural classes. }\end{array}$ & 3.31 & 0.99 & 6 & Medium \\
\hline 11 & $\begin{array}{l}\text { Introducing the importance of defining the } \\
\text { expectations of personal and social behavior of } \\
\text { students with behavioral disorders and autism from } \\
\text { different environments. }\end{array}$ & 3.50 & 0.90 & 4 & High \\
\hline 12 & $\begin{array}{l}\text { Understanding the methods of designing learning } \\
\text { environments that accomplish emotional and } \\
\text { psychological safety for students with behavioral } \\
\text { disorders and autism. }\end{array}$ & 3.63 & 0.93 & 1 & High \\
\hline Total & & 3.48 & 0.96 & - & High \\
\hline
\end{tabular}

Data in table 4 provides pre-service teachers' ratings of the effectiveness of their preparation at PNU to work with the students with behavioral disorders and autism related to the elements of Standard 2. All were rated with a high degree of satisfaction with the exception of "acquiring the basics of dealing with a group of the different cultural classes". Results indicated a medium degree of satisfaction (mean of 3.31). The element rated most effective was "understanding the methods of designing learning environments that accomplish emotional and psychological security for students with behavioral disorders and autism" which achieved a mean of (3.63). 
Focus Area Two: Learner and Learning

Content Knowledge and Professional Foundations

Table 5 Pre-service special education teachers' responses to the items of standard 3: Curricular Knowledge Content

\begin{tabular}{|l|l|l|l|l|l|}
\hline No. & Standard & $\begin{array}{l}\text { Arithmetic } \\
\text { Mean }\end{array}$ & $\begin{array}{l}\text { Standard } \\
\text { deviation }\end{array}$ & Ranking & Responses \\
\hline 13 & $\begin{array}{l}\text { Introducing the basic theories and philosophies of } \\
\text { developing curricula and educational practices for } \\
\text { the students with behavioral disorders and autism }\end{array}$ & 3.65 & 0.93 & 3 & High \\
\hline 14 & $\begin{array}{l}\text { Identifying the technological means that } \\
\text { contribute to planning, management of the } \\
\text { educational process, and educational environment. }\end{array}$ & 3.44 & 0.97 & 6 & High \\
\hline 15 & $\begin{array}{l}\text { A clear sequence of the general and private } \\
\text { educational levels }\end{array}$ & 3.49 & 0.95 & 5 & High \\
\hline 16 & $\begin{array}{l}\text { Introducing the way of merging emotional, social, } \\
\text { and life skills with curricula. }\end{array}$ & 3.53 & 0.97 & 4 & High \\
\hline 17 & $\begin{array}{l}\text { Learning certain strategies of dealing with } \\
\text { students with behavioral disorders and autism. }\end{array}$ & 3.69 & 0.94 & 2 & High \\
\hline 18 & $\begin{array}{l}\text { Illustrating the systems and ethical principles of } \\
\text { implementing behavior management }\end{array}$ & 3.84 & 0.91 & 1 & High \\
\hline Standard 3: Curricular Content Knowledge & 3.61 & 0.96 & High \\
\hline
\end{tabular}

Table 5 shows the effectiveness of Special Education Program, College of Education, PNU in preparing the female teachers of special education to work with the students with behavioral disorders and autism on "Curricular Knowledge Content" and its items with a high degree. Its most effective sub-standard was "illustrating the systems and ethical principles of implementing behavior management" with a mean of (3.61), while its least effective one was "Identifying the technological means that contribute to planning, management of the educational process, and educational environment" with a mean of (3.44).

Table 6 Pre-service special education teachers' responses to the items of standard 4: Assessment

\begin{tabular}{|l|l|l|l|l|l|}
\hline No. & Standard & $\begin{array}{l}\text { Arithmetic } \\
\text { Mean }\end{array}$ & $\begin{array}{l}\text { Standard } \\
\text { deviation }\end{array}$ & Ranking & Responses \\
\hline 19 & $\begin{array}{l}\text { Introducing the basic theories and philosophies of } \\
\text { developing curricula and educational practices for } \\
\text { the students with behavioral disorders and autism }\end{array}$ & 3.88 & 0.89 & 1 & High \\
\hline 20 & $\begin{array}{l}\text { Identifying the technological means that } \\
\text { contribute to planning, management of the } \\
\text { educational process, and educational environment. }\end{array}$ & 3.57 & 0.99 & 3 & High \\
\hline 21 & $\begin{array}{l}\text { A clear sequence of the general and private } \\
\text { educational levels }\end{array}$ & 3.57 & 0.96 & 2 & High \\
\hline 22 & $\begin{array}{l}\text { Introducing the way of merging emotional, social, } \\
\text { and life skills with curricula. }\end{array}$ & 3.23 & 0.97 & 6 & Medium \\
\hline 23 & $\begin{array}{l}\text { Learning certain strategies of handling students } \\
\text { with behavioral disorders and autism. }\end{array}$ & 3.43 & 1.02 & 4 & High \\
\hline 24 & $\begin{array}{l}\text { Illustrating the systems and ethical principles of } \\
\text { implementing behavior management }\end{array}$ & 3.41 & 0.98 & 5 & High \\
\hline Standard 4: Assessment & 3.51 & 0.99 & High \\
\hline
\end{tabular}

Table 6 shows the effectiveness of Special Education Program, College of Education, PNU in preparing the female teachers of special education to work with the students with behavioral disorders and autism on "Assessment" and its items with a high degree, except for "introducing the way of merging emotional, social, and life skills with curricula". It was indicated that it was effective with a mean of (3.23). Its most effective substandard was "Introducing the basic theories and philosophies of developing curricula and educational practices for the students with behavioral disorders and autism". 
Table 7 Pre-service special education teachers' responses to the items of standard 5: Instructional Planning and Strategies

\begin{tabular}{|l|l|l|l|l|l|}
\hline No. & Standard & $\begin{array}{l}\text { Arithmetic } \\
\text { Mean }\end{array}$ & $\begin{array}{l}\text { Standard } \\
\text { deviation }\end{array}$ & Ranking & Responses \\
\hline 25 & $\begin{array}{l}\text { Utilizing evidences in instructional planning to } \\
\text { check the appropriateness of educational practices } \\
\text { for the learner specific features. }\end{array}$ & 3.42 & 0.94 & 4 & High \\
\hline 26 & $\begin{array}{l}\text { Adopting appropriate strategies to facilitate } \\
\text { inclusion in the different environments }\end{array}$ & 3.41 & 0.97 & 5 & High \\
\hline 27 & $\begin{array}{l}\text { Acquiring different methods and strategies to } \\
\text { modify behavior. }\end{array}$ & 3.95 & 0.95 & 1 & High \\
\hline $\begin{array}{l}\text { Acquiring strategies that facilitate the } \\
\text { generalization of skills in the various learning } \\
\text { environment. }\end{array}$ & 3.51 & 1.01 & 3 & High \\
\hline 29 & $\begin{array}{l}\text { Learning the strategies of developing self- } \\
\text { awareness, self-management, self-discipline, and } \\
\text { problem-solving. }\end{array}$ & 3.58 & 1.03 & 2 & High \\
\hline Standard 5: Instructional Planning and Strategies & 3.57 & 1.00 & High \\
\hline
\end{tabular}

Table 7 shows the pre-service special education teachers' perceptions of the teacher preparation program in the college of education at Princess Norah University in Saudi Arabia on "Instructional Planning and Strategies" and its items with a high degree. Its most effective sub-standard was "Acquiring different methods and strategies to modify behavior" that achieved a mean of (3.95), while its least effective one was "adopting appropriate strategies to facilitate inclusion in the different environments" with a mean of (3.41).

Table 8 Pre-service special education teachers' responses to the items of standard 6: Professional Learning and Ethical Practice

\begin{tabular}{|l|l|l|l|l|l|}
\hline No. & Standard & $\begin{array}{l}\text { Arithmetic } \\
\text { Mean }\end{array}$ & $\begin{array}{l}\text { Standard } \\
\text { deviation }\end{array}$ & Ranking & Responses \\
\hline 30 & $\begin{array}{l}\text { Acquiring the ethical and professional values of } \\
\text { the teacher of students with behavioral disorders } \\
\text { and autism. }\end{array}$ & 4.06 & 0.91 & 1 & High \\
\hline $\begin{array}{l}\text { Illustrating the impact of personal attitudes on } \\
\text { working with the students with behavioral } \\
\text { disorders and autism. }\end{array}$ & 3.89 & 0.95 & 4 & High \\
\hline 32 & $\begin{array}{l}\text { Introducing the importance of continuous } \\
\text { learning and self-evaluation of the teacher. }\end{array}$ & 3.92 & 0.91 & 3 & High \\
\hline 33 & $\begin{array}{l}\text { Introducing the rules and regulations regarding } \\
\text { behavioral disorders and autism. }\end{array}$ & 3.71 & 1.00 & 5 & High \\
\hline $\begin{array}{l}\text { Illustrating the rights and duties of students with } \\
\text { behavioral disorders and autism as well as the role } \\
\text { of teacher, family, and school. }\end{array}$ & 4.00 & 0.94 & 2 & High \\
\hline Standard 6: Professional Learning and Ethical Practice & 3.91 & 0.95 & High \\
\hline
\end{tabular}

Table 8 shows the effectiveness of Special Education Program, College of Education, PNU in preparing the female teachers of special education to work with the students with behavioral disorders and autism on "Professional Learning and Ethical Practice" and its items with a high degree. While "Acquiring the ethical and professional values of the teacher of students with behavioral disorders and autism" was ranked first with a mean of (4.06), the least effective sub-standard was "Introducing the rules and regulations regarding behavioral disorders and autism" with a mean of (3.71). 
Table 9 Pre-service special education teachers' responses to the items of standard 7: Collaboration

\begin{tabular}{|l|l|l|l|l|l|}
\hline No. & Standard & $\begin{array}{l}\text { Arithmetic } \\
\text { Mean }\end{array}$ & $\begin{array}{l}\text { Standard } \\
\text { deviation }\end{array}$ & Ranking & Responses \\
\hline 36 & $\begin{array}{l}\text { Acquiring the skills of collaboration with the } \\
\text { family and society to serve students with } \\
\text { behavioral disorders and autism. }\end{array}$ & 3.83 & 0.95 & 1 & High \\
\hline $\begin{array}{l}\text { Displaying the various samples and methods of } \\
\text { collaboration and consultation. }\end{array}$ & 3.58 & 0.96 & 3 & High \\
\hline $\begin{array}{l}\text { Acquiring strategies that help in the participation of } \\
\text { students with behavioral disorders and autism, their } \\
\text { families, and local community members in } \\
\text { planning for the individual program. }\end{array}$ & 3.57 & 1.01 & 4 & High \\
\hline 38 & $\begin{array}{l}\text { Acquiring how to make positive relationships } \\
\text { between the family and community. }\end{array}$ & 3.78 & 0.97 & 2 & High \\
\hline 39 & $\begin{array}{l}\text { Introducing the organizations and services related } \\
\text { to students with behavioral disorders and autism. }\end{array}$ & 3.47 & 0.99 & 5 & High \\
\hline Standard 7: Collaboration & 3.65 & 0.99 & High & \\
\hline
\end{tabular}

Table 9 shows the pre-service special education teachers' perceptions of the teacher preparation program in the college of education at Princess Norah University in Saudi Arabia on "Collaboration" and its items with a high degree. While "Acquiring the skills of collaboration with the family and society to serve students with behavioral disorders and autism" was ranked the most effective with a mean of (3.83), the least effective was "Introducing the organizations and services related to students with behavioral disorders and autism".

What are the strengths and weaknesses for growth and recommended changes for the current pre-service special education program at PNU?

Table 16 shows the strengths and weaknesses for growth and recommended changes for the current pre-service special education program at PNU

\begin{tabular}{|c|c|c|c|}
\hline Strengths & Frequency & Weaknesses & Frequency \\
\hline Field Observation course & $24.6 \%$ & $\begin{array}{l}\text { Lack of the opportunities available } \\
\text { for the pre-service special education } \\
\text { teachers in program planning. }\end{array}$ & $0.78 \%$ \\
\hline $\begin{array}{l}\text { Learning strategies and methods and their } \\
\text { varieties }\end{array}$ & $3.13 \%$ & Duplicating some topics & $14.06 \%$ \\
\hline \multirow[t]{2}{*}{ Content sequencing } & $1.56 \%$ & $\begin{array}{l}\text { Lack of information that help the } \\
\text { pre-service special education } \\
\text { teachers in the field training }\end{array}$ & $0.39 \%$ \\
\hline & & $\begin{array}{l}\text { Contradiction of the information in } \\
\text { the same course and other courses }\end{array}$ & $2.34 \%$ \\
\hline Collaboration of the female faculty & $4.30 \%$ & Lack of field observation & $3.90 \%$ \\
\hline $\begin{array}{l}\text { Plenty of practical projects, case studies, and } \\
\text { training courses of the scales }\end{array}$ & $2.34 \%$ & Plenty of required reports & $1.17 \%$ \\
\hline $\begin{array}{l}\text { Educating the society of the characteristics of } \\
\text { students with special needs }\end{array}$ & $0.39 \%$ & Absence of specialization & $0.39 \%$ \\
\hline $\begin{array}{l}\text { Developing the specialized staff in } \\
\text { rehabilitation and special education }\end{array}$ & $1.56 \%$ & $\begin{array}{l}\text { Absence of good planning of the } \\
\text { courses }\end{array}$ & $1.17 \%$ \\
\hline Collaborative learning & $1.95 \%$ & Lack of practical activities & $0.39 \%$ \\
\hline Developing and updating the courses & $2.34 \%$ & $\begin{array}{l}\text { Limitedness of the courses to two } \\
\text { only }\end{array}$ & $1.95 \%$ \\
\hline Strength and experience of the faculty & $1.95 \%$ & $\begin{array}{l}\text { Incomprehensiveness of the field } \\
\text { training }\end{array}$ & 0.39 \\
\hline $\begin{array}{l}\text { Introducing work environment to the pre- } \\
\text { service special education teachers }\end{array}$ & $0.39 \%$ & $\begin{array}{l}\text { Weakness of the female faculty's } \\
\text { performance }\end{array}$ & $3.90 \%$ \\
\hline Comprehensiveness of the program & $0.78 \%$ & $\begin{array}{l}\text { Absence of training on treating } \\
\text { children with behavioral disorders }\end{array}$ & $4.30 \%$ \\
\hline Multiplicity of learning resources & $0.39 \%$ & $\begin{array}{l}\text { Abundance of group activities and } \\
\text { lack of individual ones }\end{array}$ & $1.17 \%$ \\
\hline $\begin{array}{l}\text { Just and fair treatment with the pre-service } \\
\text { special education teachers }\end{array}$ & $0.39 \%$ & $\begin{array}{l}\text { Lack of discussing autism disorders } \\
\text { in the four levels }\end{array}$ & $3.52 \%$ \\
\hline
\end{tabular}




\begin{tabular}{|l|l|l|l|}
\hline \multicolumn{1}{|c|}{ Strengths } & Frequency & \multicolumn{1}{|c|}{ Weaknesses } & Frequency \\
\hline Effective community participation & $0.39 \%$ & $\begin{array}{l}\text { Absence of interacting with the pre- } \\
\text { service special education teachers }\end{array}$ & $0.39 \%$ \\
\hline & & $\begin{array}{l}\text { Abundance of pre-service special } \\
\text { education teachers in the classroom }\end{array}$ & $1.95 \%$ \\
\hline & $\begin{array}{l}\text { Absence of benefiting from field } \\
\text { observations }\end{array}$ & $1.17 \%$ \\
\hline & $\begin{array}{l}\text { Studying on an unreal and ideal } \\
\text { environment }\end{array}$ & $0.78 \%$ \\
\hline & No course updates & $2.34 \%$ \\
\hline & Exam stress & $1.17 \%$ \\
\hline & & Lack of specialized courses & $1.56 \%$ \\
\hline & \begin{tabular}{l} 
Plenty of projects sequencing in some courses \\
\hline
\end{tabular} & $\begin{array}{l}\text { Lack of contracting with training } \\
\text { centers }\end{array}$ & $0.39 \%$ \\
\hline & $\begin{array}{l}\text { Reliance on giving lessons } \\
\text { throughout the year }\end{array}$ & $0.78 \%$ \\
\hline & $\begin{array}{l}\text { Lack of jobs and assistance for the } \\
\text { female graduates to find work } \\
\text { opportunities }\end{array}$ & $0.39 \%$ \\
\hline & $\begin{array}{l}\text { Sudden change in plans and } \\
\text { curricula }\end{array}$ & $0.78 \%$ \\
\hline & $\begin{array}{l}\text { Shortage of courses of behavior } \\
\text { modification } \\
\text { Shortage of learning resources }\end{array}$ & $0.39 \%$ \\
\hline & Lack of teaching staff $0.39 \%$ \\
\hline & & $0.39 \%$ \\
\hline
\end{tabular}

\section{Discussion and Recommendations}

Teachers in the field of special education require extensive knowledge and skills in order to successfully work with individuals with disabilities. As such, teacher educators who prepare special education teachers who will be working with individuals with disabilities need to have specific preparation to meet their students' unique needs (Barnhill, Polloway, \& Sumutka, 2010). The CEC standards were created based on studies conducted over the past twelve years to determine the essential knowledge and skills required for highly qualified pre-service special educators (CEC, 2014). Research has identified the benefits of quality special education teacher preparation programs. Tillman, Richards, and Frank (2011) examined special educators' preparedness and identified areas of focus for program improvement to address weaknesses. The study used a mixed method approach involving 20 pre-service special educators, 20 cooperating teachers, and four university faculty members. Data collection involved observations and surveys completed by cooperating teachers; observations completed by university supervisors and authors' responses to feedback. Finally, pre-service special educators responded to forms and assessments which were part of the teacher preparation course work. Results indicated that two cooperating teachers reported negative feedback, regarding university supervisor and they reported that faculty supervisor should provide effective feedback and guidance to improve pre-service educators' skills and abilities (Tillman et al., 2011). The findings of this study revealed that the special education program at PNU has significant strengths as well as areas of deficient. The most significant strengths of the Program that were 1) availability of field training, 2) collaboration of the female faculty with pre-service special education teachers, 3) various learning strategies and methods; while the most significant weaknesses that the result highlighted are 1) repeating some topics and content, 2) absence of training on treating children with behavioral disorder, 3) lack of field observation.

More studies are needed to examine the quality of teacher preparation programs and focused on the preparation of special education teachers. Such studies are limited due to a lack of interest by researchers. Many of the current studies in special education, focus on teachers' satisfaction, attitudes, and perceptions. However, research should also be focused on the creation of effective special education teacher preparation programming (Saqr \& Tennant, 2016).

Recommendations for educational institutions include: (1) examine special education programs periodically based on the CEC standards. (2), require program faculty to submit ongoing assessment data for national and international accreditation. (3) provide training field supervision for pre-service teachers.

Currently, in Saudi Arabia the field of special education is evolving and growing in knowledge and skills. Therefore, more studies are needed to evaluate the alignment of special education programs in higher education 
institutions in Saudi Arabia with CEC standards.

\section{References}

Abduljabbar, A. M. (2004). Job Satisfaction of Regular Schools Teachers and Special Education Teachers. Arabic Journal of Special Education, 5.

Aldabas, A. R. (2015) Special Education in Saudi Arabia: History and Areas for Reform. Creative Education, 6, $1158-1167$.

Al-Hiary, G., Almakanin, H., \& Tabbal, S. (2015). Problems Faced by Pre-service Special Education Teachers in Jordan. The Journal of International Education Studies, 8, (2), 128-141. Doi: ISSN 1913-9020 E-ISSN $1913-$ 9039

Alnahdi, G. H. (2014). Special Education Teachers Transition-Related Competencies and Preparation in Saudi Arabia. International Journal of Special, 29(2), 1-9.

Alnahdi, G. H. (2014). Educational Change in Saudi Arabia. Journal of International Education Research, 10(1), $1-6$.

Alzaraa, N. (2016). Evaluating baccalaureate program of Autism spectrum and behavioral disorders at Jeddah University from student's perspectives in light of the standards of the council of exceptional children, Global Institute for Study \& Research Journal, 2(5), 1-15.

Al-Zboon, E \& Ahmad, J. (2015): Pre-service special education teachers' professionalism and preparation in terms of child sexual abuse, European Journal of Special Needs Education, DOI: 10.1080/08856257.2015.108712.

Barnhill, G. P., Polloway, E. A., \& Sumutka, B. M. (2010). A survey of personnel prepara- tion practices in autism spectrum disorders. Focus on Autism and Other Developmental Disorders, 26(2), 75-86

Bateman, B. (1982). The special educator as a pro- fessional person. Exceptional Education Quar- terly, 2(4), $57-$ 69.

Brownell, J., Ross, D., Colon, E., \& McCallum, C. (2005). Critical features of special education teacher preparation: A comparison with general teacher education. The Journal of Special Education, 38, $242-252$. Retrived: July,2016 from http://dx.doi.org/10.1177/00224669050380040601

Carlson, E., Lee, H., \& Schroll, K. (2004). Identifying attributes of high quality special education teachers. Teacher Education and Special Education, 27(4), 350-359.

Clark, C. M. (1988). Asking the right questions about teacher preparation: Contributions of research on teacher thinking. Educational Researcher, 17(2), 5-12.

Council for Exceptional Children Board of Directors. (2004). CEC Definition of a Well-Prepared Special Education Teacher. Retrieved July, 2016, from http://www.cec.sped.org/Content/NavigationMenu/ ProfessionalDevelopment/ProfessionalStandards/well-prepared-final.pdf

Council for Exceptional Children (5th ed.). (2003). What every special educator must know: Ethics, standards, and guidelines for special educators. Arlington, VA: Author.

Council for Exceptional Children (n.d.a). CEC Advanced Level Special Educator Preparation Standards. Retrieved from https:/www.cec.sped.org/Standards/Special-Educator-Professional-Preparation/CEC-Initial-andAdvanced-Preparation-Standards

Council for Exceptional Children (n.d.a). CEC initial Level Special Educator

Preparation Standards. Retrieved from https:/www.cec.sped.org/Standards/Special-Educator-ProfessionalPreparation/CEC-Initial-and-Advanced-Preparation-Standards

Conderman, G., Katsiyannis, A., Franks, D. (2001). Program Assessment Practices in Special Education Teacher Preparation Programs. Alternative Education for Children and Youth, 45:4, 182-186.

Creswell, J. WM (2008). Educational research. Planning, conducting, and evaluating quantitative and qualitative research. Upper Saddle River, NJ:Pearson.

De Arment, S. T., Reed, E., \& Wetzel, A. P. (2013). Promoting adaptive expertise: A conceptual framework for special educator preparation. Teacher Education and Special Education, 36, 217-230. Doi: 10.1177/0888406413489578.

De Arment, T. S., Angela P. Wetzel, P. A., \& Reed, E. (2013). ePortfolios: Promoting Special Educator Adaptive Expertise Through Reflection in a Web-Based Learning Community. International Journal of ePortfolio, 3(2), 149-160

Donaldson, L. A. (2015). Pre-Professional Training for Serving Children with ASD: An Apprenticeship Model of Supervision. Teacher Education and Special Education,38(1), 58-70.

Ergul ., Baydik, B., \& Demir, S. (2013). Opinions of In-Service and Pre-Service Special Education Teachers on the Competencies of the Undergraduate Special Education Programs. Educational Sciences: Theory \& Practice, 13(1), 518-522.

Fajet, W., Bello, M., Leftwich, S. A., Mesler, J. L., \& Shaver, A. N. (2005). Pre- service teachers' perceptions in beginning education classes. Teaching and Teacher Education, 21(6), 717-727. Doi:10.1016/j.tate.2005.05.002 
Hadadian, A., \& Chiang, L., (2007). Special Education and pre-service teachers. International Journal of Special Education, 22(1), 103-106.

Harvey, L. (2004). The power of accreditation: Views of academics. Journal of Higher Education Policy \& Management, 26(2), 207.

Haimour, A. I., \& Obaidat, Y. F. (2013). School Teachers' Knowledge about Autism in Saudi Arabia. World Journal of Education, 3(5), 45-56.

Heller, H. W. (1982). Professional standards for preparing special educators: Status and prospects. Exceptional Education Quarterly, 2(4), 77-86.

Heller, H. W. (1983). Special education profession-al standards: Need, value and use. ExceptionalChildren, 50, 199-204.seppHeller, H., \& Rodenhour, N. (1983). Professionalstandards. Foundation for the future. Exceptional Children 49, 294-298.

Heller, H., \& Rodenhour, N. (1983). Professional standards. Foundation for the future. Exceptional Children 49 , 294-298.

Hussain, O. (2010) Evaluation of preparation program for teachers specializing in learning disabilities in Saudi Arabia (Unpublished doctoral dissertation). The University of New Mexico, Albuquerque.

The Council for Exceptional Children. Special education transition specialists. Retrieved from http://www.cec.sped.org/Content/NavigationMenu/ProfessionalDevelopment/ProfessionalStandards/Spe cial_Education_Transition_Specialist.doc

Tillman, A. B. Richards, B. S., \& Frank, L. C. (2011). A Mixed-Methods Study Assessing Special Education Preservice Candidates' Preparedness for Their First Year of Teaching. Journal of Educational Research and Practice, 1(1), 50-66.

Jabery (2013). Special Education Practicum At The University of Jordan: Preliminary Indicators of Students' Satisfaction and Concerns. International Journal of Special Education, 28 (1), 101-110.

Laura T. Zionts, Suzanne M. Shellady \& Paul Zionts (2006) Teachers' Perceptions of Professional Standards: Their Importance and Ease of Implementation, Preventing School Failure: Alternative Education for Children and Youth, 50:3, 5-12, DOI: 10.3200/PSFL.50.3.5-12. Retrieved from http://dx.doi.org/10.3200/PSFL.50.3.5-12

Lovingfoss, D., Molloy, D. E., Harris, K. R., \& Graham, S. (2001). Preparation, Practice, and Program Reform: Crafting the University of Maryland's Five-Year, Multicategorical Undergraduate Program in Special Education. The Journal of Special Education, 35(2), 105-114.

Malouf, D. B., \& Schiller, E. P. (1995). Practice and research in special education. Exceptional Children, 61, 414424.

Mason-William, L., Frederick, J. R., Mulcahy, A. C. (2014). Building Adaptive Expertise and Practice-Based Evidence: Applying the Implementation Stages Framework to Special Education Teacher Preparation.

Teacher Education and Special Education, 1-14.

Murphy, P. K., Delli, L. A. M., \& Edwards, M. N. (2004). The good teacher and good teaching: Comparing beliefs of second-grade students, pre- service, and in-service teachers. Journal of Experimental Education, 72(2), 69 92.

Murray, F. B. (2000). The role of accreditation reform in teacher education. Education Policy, 14(1), 40-59.

Murray, F. B. (2001). From consensus standards to evidence of claims: Assessment and accreditation in the case of teacher education. New directions for higher education (pp. 49-66). San Francisco: Jossey-Bass

Murry \& Alqahtani (2015). Teaching Special Education Law in Saudi Arabia: Improving Pre-Service Teacher Education and Services to Student with Disabilities. World Journal of Education, 5 (6), 57-64.

O'Shea, J. L., Stoddard, K., \& O'Shea, D. (2000). IDEA '79 and educator standards: Special Educators' perceptions of their skills and those of general educators. Teacher Education and Special Education, 23(2), 125-141

Paul, J. L., Epanchin, B. C., Rosselli, H. C., \& Duchnowski, A. J. (1996). The transformation of teacher education and special education: Work in progress. Remedial and Special Education, 17, 310-322.

Pavri, S. (2004). General and Special Education Teachers' Preparation Needs in Providing Social Support: A needs Assessment. Teacher Education and Special Education, 27(4), 433-443.

Sands, D. J., Adams, L., \& Stout, D. M. (1995). A statewide exploration of the nature and the use of curriculum in special education. Exceptional Children, 62, 68-83.

Saqr, S., \& Tennant, L. (2016) Emirati General Education Pre-service Teachers' Preparedness for Diversity in Inclusive Classrooms International Journal of Education, 8 (2), 105-121.

Simpson, L. R., Whelan, J. R., \& Zabel, H. R. (1993). Special education personnel preparation in the $21^{\text {st }}$ century: Issue and strategies. Remedial and Special Education, 14(2), 7-22.

Zahorik, J. A. (1984). Can teachers adopt research findings? Journal of Teacher Education, 35, 34-36.

Zionts, T. L., Shellady, M. S., \& Zionts, p. (2006). Teacher' Perceptions of Professional Standards: Their Importance and Ease of Implementation. Preventing School Failure,50 (3),5-12. 